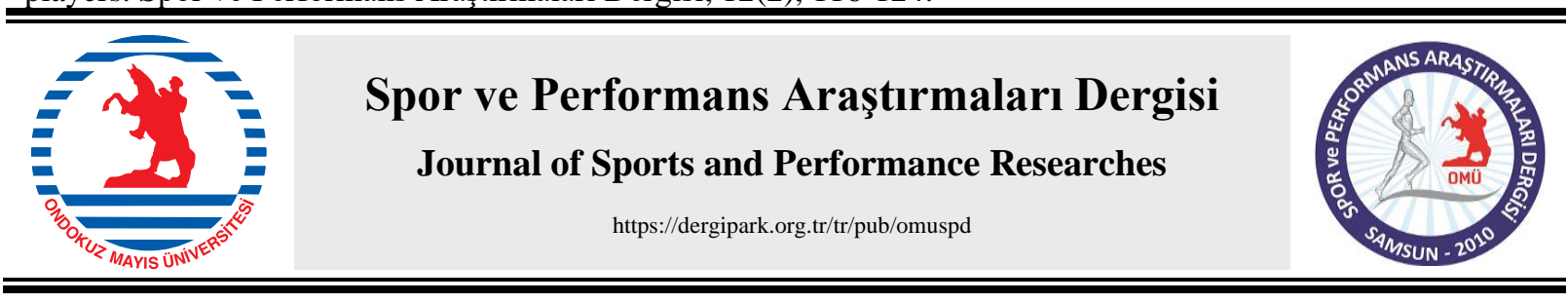

Geliş Tarihi/Received : 07.01.2021 Kabul Tarihi/Accepted : 26.06.2021

DOI: $10.17155 /$ omuspd. 856163

\title{
ACUTE EFFECT OF FOAM ROLLER APPLIED AT DIFFERENT FREQUENCY LEVELS ON FLEXIBILITY IN AMPUTEE PLAYERS

\author{
Gürkan GÜNAYDIN
}

\begin{abstract}
More than one method has been developed to increase flexibility. One of these methods is foam rolling applications. Although they have different forms, vibrating foam rollers have different frequencies. This study aims to determine the effects of foam roller application applied at different frequency levels on flexibility. Twenty male amputee athletes participating in the study were randomly divided into two groups. Then the flexibility levels of the players were evaluated. After the measurement, vibrating foam rollers with a frequency of $32 \mathrm{~Hz}$ and $62 \mathrm{~Hz}$ were applied to the 1st and 2nd groups, respectively. Finally, the flexibility measurement was repeated. For the data analysis, $2 \times 2$ repeated measures ANOVA was used. As a result of the analyses performed to determine the changes in the range of motion, the main time effect was found to be significant ( $p$ $<0.001$ ), while the time and group interaction were not significant $(\mathrm{p}=0.75)$. Post Hoc analysis showed that the foam roller application with both frequencies was significant $(\mathrm{p}<0.001)$ in increasing range of motion. However, frequency differences do not affect flexibility levels $(\mathrm{p}=0.52)$. The result of this study indicates that the application of vibration foam rolling at different frequency levels is an effective method to increase range of motion. It is also seen that increasing the frequency level does not affect flexibility.
\end{abstract}

Keywords: Amputees, athletes, flexibility, range of motion, vibration

\section{AMPUTE FUTBOLCULARDA FARKLI FREKANS SEVIYELERINDE UYGULANAN FOAM ROLLER'IN NORMAL EKLEM HAREKETI ÜZERINE AKUT ETKISİ}

\section{$\ddot{O Z Z}$}

Esnekliğin artırılması için birden fazla yöntem geliştirilmiştir. Bu yöntemlerden biri de foam rolling uygulamalarıdır. Değişik formları olmakla beraber titreşimli foam rollerin farklı frekansları bulunmaktadır. $\mathrm{Bu}$ çalışmanın amacı farklı frekans seviyelerinde uygulanan foam roller uygulamasının esnekliğe etkilerinin belirlenmesidir. Çalışmaya katılan 20 erkek ampute sporcu randomize şekilde 2 gruba ayrılmıştır. Daha sonra oyuncuların esneklik seviyeleri değerlendirilmiş̧ir. Ölçüm sonrası 1. gruba $32 \mathrm{~Hz}, 2$. gruba ise $62 \mathrm{~Hz}$ frekansa sahip titreşimli foam roller uygulanmıştır. Son olarak esneklik ölçümü tekrar edilmiştir. Verilerin analizi için $2 \times 2$ tekrarlı ölçümlerde ANOVA testi kullanılmıştır. Normal eklem hareketi değişimlerinin belirlenmesi için yapılan analizler neticesinde ana zaman efekti anlamlı bulunurken $(\mathrm{p}<0.001)$, zaman ve grup etkileşimi anlamlı bulunmamıştır. Post Hoc analizlerinde her iki frekansa sahip uygulamanın da normal eklem hareketini arttırmada anlamlı $(\mathrm{p}<0.001)$ olduğu görülmüştür. Ancak frekans farklıllkları esneklik seviyelerine etki etmemektedir $(\mathrm{p}=0.524)$. Bu çalışma sonucu farklı frekans seviyelerinde uygulanan foam rolling uygulamasının normal eklem hareketini arttırmada etkin bir yöntem olduğuna işaret etmektedir. Ayrıca frekans artırımının esneklik üzerine bir etki oluşturmadığı da görülmektedir.

Anahtar Kelimeler: Amputeler, esneklik, normal eklem hareketi, sporcular, titreşim

Yazışmadan sorumlu yazar: Gürkan GÜNAYDIN, gunaydingrkn@gmail.com Aydın Adnan Menderes Üniversitesi, Sağlık Bilimleri Fakültesi, Fizyoterapi ve Rehabilitasyon Bölümü, ORCID: 0000-0003-3432-6431 


\section{INTRODUCTION}

Flexibility plays an important role in ensuring human movement by creating the range of motion (Junker et al., 2015). Besides its effect on functionality, its possible relationship with injury and performance is also striking (Behm et al., 2016; Medeiros et al., 2016; Wanderley et al., 2019). For this reason, flexibility and related studies have long attracted the attention of clinicians, trainers, and researchers.

Although there are many methods to improve flexibility in the literature, it is possible to divide these techniques into stretching and myofascial techniques. Stretching techniques mainly consist of static, dynamic, and proprioceptive neuromuscular facilitation stretching techniques. Myofascial techniques include active and passive myofascial release (Page, 2012; Junker et al., 2015). Among the passive myofascial release techniques, recently, the most common technique is foam rolling applications. Foam rolling application is defined as a selfrelease application that has vibrating and non-vibrating forms and is mostly made of foam (Cheatham et al., 2015; Kalichman et al., 2017; Wilke et al., 2020).

Although there are many studies on vibrating and non-vibrating foam rollers in the literature, it has been shown that both forms are effective in increasing range of motion (Romero-Moraleda et al., 2019; Wilke et al., 2020). However, there are different modes of vibrating foam roles and these modes create different frequency levels. These modes generally have $20 \mathrm{~Hz}, 32 \mathrm{~Hz}$, alternating mode, and $62 \mathrm{~Hz}$ frequency. Applications with a frequency of $20 \mathrm{~Hz}$ can generally be used for relaxation (Lim and Park, 2019). Techniques with $32 \mathrm{~Hz}$ and $62 \mathrm{~Hz}$ frequencies are used to increase flexibility (Han et al., 2017; Cheatham et al., 2019). Although both frequencies are effective in increasing range of motion, the change caused by frequency differences on flexibility is unknown. For this reason, this study aims to examine the acute effect of foam roles applied at different frequency levels on flexibility.

\section{MATERIAL AND METHODS}

\section{Subjects}

This study was conducted with male Turkish Amputee Football National Team players participating in the training camp. The necessary ethics committee permission to carry out this study was obtained from Aydın Adnan Menderes University Non-Invasive Clinical Research Ethics Committee prior to the study with the protocol number 92340882-050.04.04 and 2020/024 on 22.04.2020. Before the study, informed consent form was received from all 
participants and the principles in the Declaration of Helsinki were followed at all stages of the study.

Twenty-four Amputee Football National Team players were reached for the study. While players between the ages of 18-45 who did not use muscle relaxants were included in the study, those who had surgery on their upper or lower extremities in the last 1 year were excluded. The study was completed with 20 players who met these criteria.

\section{Design}

First of all, players that had lower extremity amputation were randomly divided into two groups. Then, hamstring flexibility from intact lower extremity of both groups was measured. After the flexibility measurement was completed, vibration foam rolling exercises were started. While the 1 st group was subjected to foam roller application with a frequency of 32 $\mathrm{Hz}$, foam rollers with a frequency of $62 \mathrm{~Hz}$ were applied to the 2nd group. Finally, flexibility levels were measured again.

\section{Assessments}

\section{Range of motion measurement}

The range of motion values of the participants were measured in the supine position. While the amputee athletes were in this position, their intact side hips were placed in a 90degree flexion. Later, while maintaining this position, the players were asked to actively extend their intact lower extremity from knee and the angle was recorded. Range of motion assessment was measured with Goniometer Pro, a mobile application whose validity and reliability was previously made (O'Sullivan et al., 2009; Lim et al., 2015; Pourahmadi et al., 2016). The measurements were repeated twice and the best value was included in the analysis.

\section{Vibration foam roller application}

For the application, the participants were placed on the exercise bed in a long sitting position. Then the foam roller was placed under the thigh (intact lower extremity side). Foam rollers, which were adjusted to different frequencies for each group (1st group: $32 \mathrm{~Hz}$, 2nd group: $62 \mathrm{~Hz}$ ), were applied in 5 repetitions in 30 seconds of exercise and 30 seconds of rest. While the vibration foam roller was active, the athlete was asked to move back and forth with his own body weight according to the metronome set to 60 bpm (Lim et al., 2015; Ajlan et al., 2018; Ateş and Yitik, 2018; Kiyono et al., 2020).

\section{Statistical analyses}

The obtained data were analyzed with IBM SPSS Statistics (Version 21 for Mac; IBM, Armonk, NY, USA). To compare the range of motion data of both groups, $2 \times 2$ repeated measures ANOVA test was used. The significance level was defined as $\mathrm{p}<0.05$. 


\section{RESULTS}

Twenty amputee players participated in the study and of the 20 football players 10 had the right and the other 10 had the left lower extremity amputation. Of these players, 14 had above knee, 3 at knee and 3 have below the knee amputation. The detailed demographic data of players is summarized in Table 1. As a result of $2 \times 2$ repeated measures ANOVA analysis performed to compare the flexibility values, the main time effect was significant $[F(1,18)=$ 43.599, p <0.001, partial eta squared=0.708], but time and group interaction was not statistically significant $[F(1,18)=0.102, p=0.75$, partial eta squared $=0.006]$. In the Post Hoc analyzes, it is understood that the vibration foam rolling application with both frequency levels increases flexibility within the group ( $\mathrm{p}<0.001$ ). In the comparisons between the groups, it is seen that there is no flexibility difference before $(p=0.65)$ and after $(p=0.52)$ the vibration foam rolling exercise. ICC results for the repeated range of motion analyses and the changes of the range of motion values in both groups are shown in Table 2.

Table 1. Demographic data of the players

\begin{tabular}{cccc}
\hline Parameters & $\begin{array}{c}\text { Total } \\
(\mathbf{n = 2 0})\end{array}$ & $\begin{array}{c}\text { First Group (32 Hz) } \\
(\mathbf{n = 1 0})\end{array}$ & $\begin{array}{c}\text { Second Group (62 Hz) } \\
(\mathbf{n = 1 0})\end{array}$ \\
\hline Age (years) (mean $\pm \mathrm{sd})$ & $27.25 \pm 6.16$ & $27.50 \pm 7.28$ & $27.00 \pm 5.21$ \\
Height $(\mathrm{cm})$ & $175.90 \pm 5.57$ & $175.60 \pm 6.82$ & $176.20 \pm 4.34$ \\
Weight $(\mathrm{kg})$ & $67.65 \pm 6.63$ & $69.60 \pm 5.91$ & $65.70 \pm 7.02$ \\
Amputation side & left:10, rigth:10 & left:5, right:5 & left:5, right:5 \\
Amputation level & AN:3, K: 3, & K:3, BK:7 & AN:3, BK:7 \\
\hline
\end{tabular}

AN: Above knee amputation, K: Knee amputation, BK: Below knee amputation

Table 2. Rom and ICC values

\begin{tabular}{ccccc}
\hline $\begin{array}{c}\text { Group } \\
\text { Frequencies }\end{array}$ & $\begin{array}{c}\text { Pre-VFR* Rom** } \\
(\text { mean } \pm \text { sd) }\end{array}$ & $\begin{array}{c}\text { Post-VFR* Rom** } \\
(\text { mean } \pm \text { sd) }\end{array}$ & p & Cohen's d \\
\hline $32 \mathrm{~Hz}$ & $83.30 \pm 9.84$ & $89.20 \pm 9.59$ & $<0.001$ & 0.61 \\
$62 \mathrm{~Hz}$ & $85.10 \pm 7.29$ & $91.60 \pm 6.65$ & $<0.001$ & 0.93 \\
\hline ICC (95\% Confidence Interval) & $0.972(0.929-0.989)$ & $0.975(0.937-0.990)$ & & \\
(Lover-Upper Bound) & & & & \\
\hline$*$ : vibration foam rolling $* * *$ range of & & &
\end{tabular}

\footnotetext{
*: vibration foam rolling, **: range of motion of intact lower extremity
} 


\section{DISCUSSION}

As a result of this study, it is seen that the vibrating foam rolling application with different frequency levels is an effective method to increase the range of motion. However, raising the frequency does not make a difference in terms of flexibility level.

It is known that a sufficient level of flexibility provides positive effects for muscles and joints. It is claimed to be able to reduce pain and the risk of injury while improving efficiency in all physical activities. It is also stated that increased flexibility may contribute to increasing the quality of life and functional independence by providing a wider range of motion to the joints (Nelson and Kokkonen, 2007). For this reason, physiotherapists, athletic trainers, and clinicians have carried out many studies to increase flexibility. As a result of these studies, more than one technique has emerged in increasing flexibility. Stretching techniques are the most preferred method among these techniques. Although these techniques have proven to be effective in increasing range of motion (Harvey et al., 2002; Radford et al., 2006), there is concern that stretching exercises may cause a deterioration in muscle function (Simic et al., 2013; Behm et al., 2016). As an alternative to stretching techniques, myofascial release techniques such as massage bars and massage rollers have been used widely (Cheatham, 2019; Wilke et al., 2020). It is claimed that applications of myofascial release may increase range of motion and at the same time not create a loss in athletic performance (Cheatham et al., 2015; Kalichman et al., 2017).

One of the most popular applications among myofascial release techniques is foam rolling applications. Although there are several versions, it is shown that vibrating foam rolling applications are an effective method for increasing flexibility (Han et al., 2017; Cheatham et al., 2019). However, vibrating foam rollers have different frequency levels and it is not known whether these different levels are superior to each other in increasing flexibility. Therefore, this study can provide important contributions to the field by filling the gap in the literature.

There are many studies in the literature regarding the effectiveness of foam rollers. Lim et al. point out that the vibrating foam rolling application with a frequency of $32 \mathrm{~Hz}$ is more effective in increasing flexibility than the non-vibration version (Lim and Park, 2019). Cheatham et al. also state that $33 \mathrm{~Hz}$ vibrating foam rolling application is effective in increasing flexibility compared to non-vibration roller and control group (Cheatham et al., 2019). The study of Han et al., where $62 \mathrm{~Hz}$ vibrating foam roller is applied, similarly indicate that vibrating foam rollers are an application that may be preferred in increasing range of 
motion (Han et al., 2017). Likewise, this study indicates that the vibrating foam rolling exercise is an effective method in increasing the range of motion. Based on this, several theories have been developed on the action mechanism of vibrating foam rollers in increasing flexibility. The first of these is based on the pain mechanism. It has been claimed that vibrating foam rollers can increase stretching performance by reducing the pain (Heo et al., 2008; Han et al., 2017). According to another view, it is stated that the application of vibrating foam rollers provides a relaxation in the fascia by regulating the arterial, vascular endothelial, and autonomic nervous system, thereby increasing the range of motion in the relevant joint (Kalichman et al., 2017; Lim and Park, 2019). Another view has drawn attention to the fact that the vibration application may increase the stretching tolerance due to the change in the viscoelastic elements of the musculotendinous unit, thereby increasing range of motion (Morse et al., 2008; Ryan et al., 2009; Weppler and Magnusson, 2010; GarcíaGutiérrez et al., 2018). However, it should be kept in mind that there is not enough evidence support for all these theories and more studies are needed to reveal the effect mechanism of foam rollers in increasing range of motion.

To our knowledge, a study design similar to this research was not encountered in the literature. However, there is a study that adopts the main idea in this study. In their study, García-Gutiérrez et al. (2018) claim that during the foam rolling application, the participant may apply excessive force on the foam roller and that this force may reduce the effects of vibration. For this reason, they point out that higher frequencies may be required for more effective results (García-Gutiérrez et al., 2018). However, the results of this study could not confirm this idea. The possible reason for the formation of this situation may be that amputee players use crutches in the game and might transfer optimal weight on the foam rollers and upper extremities during the application. However, more studies are needed to examine this view.

This study population was conducted with amputee football players with different amputation levels. It is common to think that the change in amputation level may create differences between individuals' physical fitness parameters. However, flexibility, the physical fitness parameter evaluated in this study, was obtained from the other lower extremity. At the same time, vibration foam rolling application was applied to the intact side lower extremity too. For this reason, it may be expected that the effect of heterogeneity within the group on flexibility and application results would be minimal. Moreover, scientific research has not revealed whether the different amputation levels create a change on sports performance, flexibility, etc. in high activity level amputees. 
This study has some limitations. Foam rolling exercise was applied only to the hamstring muscle and there is no control group in this study. It may be beneficial to repeat the design with control group by applying it to different muscle groups in the lower extremity. The results of this study are interpreted over the frequency, the number of repetitions, and the time expressed in the study. New study designs may be required for the flexibility changes that may occur in different frequency and application times.

\section{CONCLUSION AND RECOMMENDATIONS}

With this study, it is seen that the vibration foam rolling applied at different frequency levels increases the range of motion, but the frequency increase does not make a difference in the level of flexibility. A $32 \mathrm{~Hz}$ frequency may be preferred by trainers, coaches, and physiotherapists in cases where high frequency values are difficult to tolerate without worrying about flexibility in their vibration foam roller usage.

\section{Information statement}

Authors' contribution: Study design: G.G, data collection: G.G, Statistical analysis: G. G, data interpretation: G.G, literature search: G.G, manuscript preparation: G.G.

The author has no conflict of interest to disclose.

\section{REFERENCES}

Ajlan, S., Aktaş, M., \& Çolak, H. (2018). Foam roller uygulamasinin kadin basketbolcularda eklem hareket genişliği, esneklik ve alt ekstremite patlayici güç üzerine etkileri. Spor ve Performans Araştırmaları Dergisi, 9(1), 35-43.

Ateş, B., \& Yitik, R. (2018). Foam roller kullanılarak gerçekleştirilen kendi kendine miyofasiyal gevşetme egzersizlerinin esneklik ve alt ekstremite gücü üzerine akut etkisi. CBÜ Beden Eğitimi ve Spor Bilimleri Dergisi, 13(2), 310-317.

Behm, D.G., Blazevich, A.J., Kay, A.D., \& McHugh, M. (2016). Acute effects of muscle stretching on physical performance, range of motion, and injury incidence in healthy active individuals: a systematic review. Applied Physiology, Nutrition, and Metabolism, 41(1), 1-11.

Cheatham, S.W., Kolber, M.J., Cain, M., \& Lee, M. (2015). The effects of self-myofascial release using a foam roll or roller massager on joint range of motion, muscle recovery, and performance: a systematic review. International journal of Sports Physical Therapy, 10(6), 827.

Cheatham, S.W., Stull, K.R., \& Kolber, M.J. (2019). Comparison of a vibration roller and a nonvibration roller intervention on knee range of motion and pressure pain threshold: a randomized controlled trial. Journal of Sport Rehabilitation, 28(1), 39-45.

Cheatham, S.W. (2019). Roller massage: a descriptive survey of allied health professionals. Journal of Sport Rehabilitation, 28(6), 640-649.

García-Gutiérrez, M.T, Guillén-Rogel, P., Cochrane, D.J., \& Marín, P.J. (2018). Cross transfer acute effects of foam rolling with vibration on ankle dorsiflexion range of motion. Journal of Musculoskeletal \& Neuronal Interactions, 18(2), 262. 
Han, S.W., Lee, Y.S., \& Lee, D.J. (2017). The influence of the vibration form roller exercise on the pains in the muscles around the hip joint and the joint performance. Journal of Physical Therapy Science, 29(10), 1844-1847.

Harvey, L., Herbert, R., \& Crosbie, J. (2002). Does stretching induce lasting increases in joint ROM? A systematic review. Physiotherapy Research International, 7(1), 1-13.

Heo, G.H., Lee, H.M., Choen, S.H., Bang, H.S., Kang, J.H., \& Kim, J.S. (2008). Effect of local vibration on elbow joint in position sense and maximal grip force. Journal of Korean Society of Physical Medicine, 3(3), 145-149.

Junker, D.H., \& Stöggl, T.L. (2015). The foam roll as a tool to improve hamstring flexibility. The Journal of Strength \& Conditioning Research, 29(12), 3480-3485.

Kalichman, L., \& David, C.B. (2017). Effect of self-myofascial release on myofascial pain, muscle flexibility, and strength: a narrative review. Journal of Bodywork and Movement Therapies, 21(2), 446-451.

Kiyono, R., Onuma, R., Yasaka, K., Sato, S., Yahata, K., \& Nakamura, M. (2020). Effects of 5-week foam rolling intervention on range of motion and muscle stiffness. Journal of Strength and Conditioning Research.

Lim, J.H., \& Park, CB. (2019). The immediate effects of foam roller with vibration on hamstring flexibility and jump performance in healthy adults. Journal of Exercise Rehabilitation, 15(1), 50.

Lim, J.Y., Kim, T.H, \& Lee, J.S. (2015). Reliability of measuring the passive range of shoulder horizontal adduction using a smartphone in the supine versus the side-lying position. Journal of Physical Therapy Science, 27(10), 3119-3122.

Medeiros, D.M., Cini, A., Sbruzzi, G., \& Lima, C.S. (2016). Influence of static stretching on hamstring flexibility in healthy young adults: Systematic review and meta-analysis. Physiotherapy Theory and Practice, 32(6), 438-445.

Morse, C.I., Degens, H., Seynnes, O.R., Maganaris, C.N., \& Jones, D.A. (2008). The acute effect of stretching on the passive stiffness of the human gastrocnemius muscle tendon unit. The Journal of Physiology 586(1), 97-106.

Nelson, A.G., \& Kokkonen, J. (2007). Stretching Anatomy. Human Kinetics.

O'Sullivan, K., Murray, E., \& Sainsbury, D. (2009). The effect of warm-up, static stretching and dynamic stretching on hamstring flexibility in previously injured subjects. BMC Musculoskeletal Disorders, 10(1), 1-9.

Page, P. (2012). Current concepts in muscle stretching for exercise and rehabilitation. International journal of Sports Physical Therapy, 7(1), 109.

Pourahmadi, M.R., Taghipour, M., Jannati, E., Mohseni-Bandpei, M.A., Takamjani, I.E., \& Rajabzadeh, F. (2016). Reliability and validity of an iPhone ${ }^{\circledR}$ application for the measurement of lumbar spine flexion and extension range of motion. Peer Journal, 4, e2355.

Radford, J.A., Burns, J., Buchbinder, R., Landorf, K.B., \& Cook, C. (2006). Does stretching increase ankle dorsiflexion range of motion? A systematic review. British Journal of Sports Medicine, 40(10), 870-875.

Romero-Moraleda, B., González-García, J., Cuéllar-Rayo, Á., Balsalobre-Fernández, C., MuñozGarcía, D., \& Morencos, E. (2019) Effects of vibration and non-vibration foam rolling on recovery after exercise with induced muscle damage. Journal of Sports Science \& Medicine, 18(1), 172.

Ryan, E.D., Herda, T.J., Costa, P.B., Defreitas, J.M., Beck, T.W., Stout, J., \& Cramer, J.T. (2009). Determining the minimum number of passive stretches necessary to alter musculotendinous stiffness. Journal of Sports Sciences, 27(9), 957-961. 
Simic, L., Sarabon, N., \& Markovic, G. (2013). Does pre-exercise static stretching inhibit maximal muscular performance? A meta-analytical review. Scandinavian Journal of Medicine \& Science in Sports, 23(2), 131-148.

Wanderley, D., Lemos, A., Moretti, E., Barros, M.B., Valença, M.M., \& de Oliveira, D.A. (2019). Efficacy of proprioceptive neuromuscular facilitation compared to other stretching modalities in range of motion gain in young healthy adults: a systematic review. Physiotherapy Theory and Practice, 35(2), 109-129.

Weppler, C.H, \& Magnusson, S.P. (2010). Increasing muscle extensibility: a matter of increasing length or modifying sensation? Physical Therapy, 90(3), 438-449.

Wilke, J., Mueller, A.L., Giesche, F., Power, G., Ahmedi, H., \& Behm, D.G. (2020). Acute effects of foam rolling on range of motion in healthy adults: a systematic review with multilevel meta-analysis. Sports Medicine, 50(2), 387-402. 